\title{
Ability of salt marsh plants for TBT remediation in sediments
}

\author{
Pedro N. Carvalho • M. Clara P. Basto • \\ Manuela F. G. M. Silva • Ana Machado •
}

A. A. Bordalo • M. Teresa S. D. Vasconcelos

Received: 4 June 2009 / Accepted: 5 February 2010

(C) Springer-Verlag 2010

\begin{abstract}
Introduction The capability of Halimione portulacoides, Spartina maritima, and Sarcocornia fruticosa (halophytes very commonly found in salt marshes from Mediterranean areas) for enhancing remediation of tributyltin (TBT) from estuarine sediments was investigated, using different experimental conditions.

Methods The influence of $H$. portulacoides on degradation of the butyltin compounds was assessed in two different ways: (1) a 9-month ex situ study carried out in a site of Sado River estuary, center of Portugal, which used polluted sediments collected at other nonvegetated site from the
\end{abstract}

Responsible editor: Elena Maestri

P. N. Carvalho $\cdot$ M. C. P. Basto $\cdot$ A. A. Bordalo

M. T. S. D. Vasconcelos $(\bowtie)$

CIMAR/CIIMAR - Centro Interdisciplinar de Investigação

Marinha e Ambiental, Universidade do Porto,

Rua dos Bragas, 289,

4050-123 Porto, Portugal

e-mail: mtvascon@fc.up.pt

P. N. Carvalho • M. C. P. Basto

Departamento de Química, Faculdade de Ciências,

Universidade do Porto,

Rua do Campo Alegre, 687,

4169-007 Porto, Portugal

M. F. G. M. Silva

Instituto Superior de Engenharia da Universidade do Algarve,

Campus da Penha,

8005-139 Faro, Portugal

A. Machado $\cdot$ A. A. Bordalo

Laboratório de Hidrobiologia,

Instituto de Ciências Biomédicas de Abel Salazar (ICBAS),

Universidade do Porto,

Largo Professor Abel Salazar, No. 2,

4099-003 Porto, Portugal same estuary; and (2) a 12-month laboratorial study, using both plant and sediment collected at a relatively clean site of Cávado River estuary, north of Portugal, the sediment being doped with TBT, DBT, and MBT at the beginning of the experiment. The role of both $S$. fruticosa and $S$. maritima on TBT remediation in sediments was evaluated in situ, in salt marshes from Marim channel of Ria Formosa lagoon, south of Portugal, which has large areas colonized by each one of these two plants. For estimation of microbial abundance, total cell counts of sediment samples were enumerated by the DAPI direct count method. Butyltin analyses in sediment were performed using a method previously validated, which consisted of headspace solid-phase micro-extraction combined with gas chromatography-mass spectrometry after in situ ethylation (with tetraethylborate).

Results Sediments colonized both ex situ and at lab by $H$. portulacoides displayed TBT levels about 30\% lower than those for nonvegetated sediments with identical initial composition, after 9-12 months of plant exposure. In addition, $H$. portulacoides showed to be able of stimulating bacterial growth in the plant rhizosphere, which probably included degraders of TBT. In the in situ study, which compared the levels of TBT, DBT, and MBT in nonvegetated sediment and in sediments colonized by either $S$. maritima or S. fruticosa from the same area, TBT and DBT were only detected in nonvegetated sediment, whereas MBT was quantified in most samples.

Discussion This work demonstrated that $H$. portulacoides has potentiality to be used for enhancing TBT remediation in sediments from salted areas. The results observed in situ for $S$. maritima or $S$. fruticosa suggested that these two salt marsh plants also favored TBT remediation.

Conclusion Therefore, the application of halophytes in technologies for TBT remediation in sediments seems to 
be efficient both in situ and ex situ, cost effective, and nondestructive, despite the fact that they have been rarely used for this purpose so far.

Keywords Sediments $\cdot$ Remediation $\cdot$ Butyltins $\cdot$ TBT

\section{Introduction}

The trisubstituted tin forms, mainly tributyltin (TBT), have been used extensively in agriculture and industry as biocides, insecticides, fungicides, wood preservations, antifouling agents, and polymer stabilizers since the mid1960s. However, the application of TBT in paints for boats has been associated to a variety of serious damages in marine organisms and in humans where TBT has been detected in blood and liver (Antizar-Ladislao 2008). TBT is an endocrine disruptor, presenting influence on marine organism even at nanogram per liter level (Birchenough et al. 2002; Hoch 2001; Liu et al. 2006). This compound has shown to be highly toxic to a wide range of living organisms, particularly to gastropods (Fent 1996) being responsible for imposex, the development of male sexual characteristics in females, capable of causing sterility (Nishikawa et al. 2004). TBT concentrations in water of less than $2.5 \mathrm{ng} \mathrm{L}^{-1}$ have shown to be sufficient to induce the development of imposex in female Nucela lapillus, and a few nanograms per liter could cause sterility in several species of gastropods (Santos et al. 2004). Thus, tributyltin constitutes a particularly toxic group of chemicals that not only represent a danger to marine organisms but also a danger to humans consuming contaminated seafood (Kennish 2001), drinking water, foodstuff, and beverages (Hoch 2001).

The Commission Directive 2002/62/EC, 9th July 2002 (presently European Union legislation) decided to specifically include TBT in the list of priority compounds in water. In 2003, the International Maritime Organization called for a ban of the organotins on the global fleet and for a total replacement of existing organotin coatings by 2008 . However, butyltin compounds continue to be included, for example, in wood preservatives (Marcic et al. 2006).

Results of experimental studies showed that clay minerals and metal oxides bearing a net negative charge are effective sorbents for several organotins under environmentally relevant conditions and that TBT half-life in sediment is reported to be up to several years. Not only TBT but also its degradation products, dibutyltin (DBT) and monobutyltin (MBT), which adsorb readily onto particles, can persist adsorbed on sediment surface (Bhosle et al. 2006; Kim et al. 2008). Therefore, sediment in marine and estuarine environments can act as source of TBT and metabolites for the water column and biota. Thus, large amounts of sediments are used to be dredged periodically from waterways and harbors to reduce sediment pollution by TBT and its metabolites. Nevertheless, technologies for TBT remediation in sediments are scarce.

Butyltin compounds have been dumped of harbor sludge into the sea (which is already prohibited in several countries) or, as alternative, land-based dumped (Novak and Trapp 2005). Physical-chemical remediation techniques or reuse of the sediment are often unacceptable because of the large volume and the high levels of contamination of the sediments. In addition, the possible effects on terrestrial ecosystems and on humans, once the sediment is applied to land, are not well known (Novak and Trapp 2005). An attempt was made to develop quality criteria for the reuse of treated organotin containing sediment on land as secondary building material. However, results were subject to large uncertainties as well as lack on high-quality data on plant uptake and soil sorption of organotins, on the influence of soil properties on these processes and on long-term terrestrial toxicity data (Cornelis et al. 2006).

Bioremediation of river sediments using bacteria has been tested in laboratory (Suehiro et al. 2006) after enrichment of sediments in TBT up to $1.0-1.4 \mathrm{mg} \mathrm{kg}^{-1}$ and could cause a reduction of about $50 \%$ of TBT level in 5 months. Marked change in the structure of the microbial community of the initial sediment has not been found, indicating that the sediment had stable microbial community against TBT pollution.

Phytoremediation of TBT from soil mixed with sludge, containing $0.049-0.122 \mathrm{mg} \mathrm{kg}^{-1}$, was tested ex situ (Lespes et al. 2009). The soil was cultivated with lettuce which could accumulate $10 \%$ of the initial TBT in about 2 months, but $85 \pm 15 \%$ remained in soil (Lespes et al. 2009). Novak and Trapp (2005) have studied the feasibility of using landdeposited harbor sludge for plant production. For this purpose, in a field trial, the growth of several salt-tolerant plant species (e.g., barley, sorghum, rape seed, clover/grass mix, and reed) on low $\left(1.6 \mathrm{mg} \mathrm{kg}^{-1}\right)$ and high $\left(43 \mathrm{mg} \mathrm{kg}^{-1}\right)$ TBT-contaminated sediments has been carried out. It was observed that TBT degradation is significantly faster $(>40 \%)$ in vegetated than in nonvegetated sites (controls), the translocation to the aboveground tissues being very low.

Ability of Spartina alterniflora to degrade TBT in contaminated dredged soils has been investigated in a created wetland (Anderson et al. 2002). It has been observed that $0.25 \mathrm{mg} \mathrm{kg}^{-1}$ TBT did not inhibit plant growth over the 16-month period. However, the plant did not improve degradation rate, as nonvegetated and vegetated treatments gave similar results. In addition, only $0.4 \%$ TBT accumulated in the plant, mainly in belowground biomass.

Therefore, the application of salt-tolerant species to enhance TBT degradation from polluted sediments has 
been a little explored topic. Some promising results as well as some other disappointing were already obtained until now, this being an open field of research. Mutual interactions between a certain plant species and the surrounding chemical environment (rhizosphere) may condition the role of a plant together with rhizosphere microorganisms on pollution distribution, degradation, and uptake.

In the present work, the capability of three plants species (Halimione portulacoides, Spartina maritima, and Sarcocornia fruticosa) for enhancing remediation of TBT from estuarine sediments were investigated, using different experimental conditions. These plants are very commonly found in salt marshes from Mediterranean areas.

\section{Methods and materials}

\subsection{Strategy and sampling}

This study included three sets of experiments, two of them using $H$. portulacoides (one in laboratory and other ex situ) and one in situ using either S. fruticosa or S. maritime.

A field campaign for the ex situ study was carried out between February and November of 2007 (9 months). In February, polluted sediment from the Lisnave area (38.4879 $\mathrm{N} ; 8.7912^{\circ} \mathrm{W}$ - near a shipyard at Sado estuary, center of Portugal) was collected into a box, homogenized and transported to Comporta site $\left(38.4425^{\circ} \mathrm{N} ; 8.8312^{\circ} \mathrm{W}-\mathrm{a}\right.$ less contaminated area of Sado estuary). The polluted sediment (see below) was translocated for a better control of the results, as the original site may receive new contamination when flooded in high tide. At Comporta site, several $750-\mathrm{mL}$ cylinder litterbags, with a sleeve form, were filled with the polluted sediment and put into holes opened in the ground, after cleaning the site to avoid a mixture between native and transplanted $H$. portulacoides (Fig. 1a, b). The litterbags allow vertical water flow and prevent roots mixture between the native and the trans- planted plants. A composite sample of the sediment used to fill the litterbags was collected for analysis $\left(P_{0}\right)$. Five $H$. portulacoides, which had been raised in hydroponic conditions (to obtain a homogenous sample of plants grown in similar conditions), were transplanted per litterbag. Similar containers filled with polluted sediment but without plants were used as controls. At the end of the study, the levels of TBT, DBT, and MBT were determined in all samples.

The laboratory study was carried out using sediments and H. portulacoides collected, in June 2007, at Cávado estuary, North of Portugal $\left(41.5228^{\circ} \mathrm{N} ; 8.7846^{\circ} \mathrm{W}\right)$. Sediment, containing only $2 \mathrm{ng}$ Sn per gram as TBT, was doped with (ng Sn per gram): 250 TBT, 750 DBT, and 1,500 MBT before plant exposure, to ensure a relatively high level of contamination, and homogenized. A composite sample of the doped sediment $\left(P_{0}\right)$ was collected for analysis. Eight vases of $1.6 \mathrm{~L}$ of capacity were pierced in the bottom to allow water circulation. Four vases only with sediment (controls) as well as four vases with sediment and two plants each were prepared. The vases were placed in the exterior of the lab building in a covered area (Fig. 1c). Weekly, the plants were supplied with one quarter-strength-modified Hoagland nutrient solution (Hoagland and Arnon 1950). Sediment samples were collected for analysis in June 2008.

The third study consisted in comparing the levels of TBT, DBT, and MBT in sediment nonvegetated and those vegetated with homogeneous stands of eight $S$. fruticosa or $S$. maritime, two halophyte species. The three sites were very near at Marim channel of Ria Formosa lagoon, South of Portugal $\left(37.0300^{\circ} \mathrm{N} ; 7.8172^{\circ} \mathrm{W}\right)$. Sampling was carried out in March 2007. Three sediment cores with $30 \mathrm{~cm}$ of depth of each studied site were collected at low tide. Each core was sliced in 5-cm thickness layers to be analyzed separately.

All the samples were collected to a polyethylene plastic bag and immediately stored in a portable refrigerator. Until analysis, samples were kept frozen at $-20^{\circ} \mathrm{C}$. Before analysis, sediments were sieved through a $2-\mathrm{mm}$ mesh with
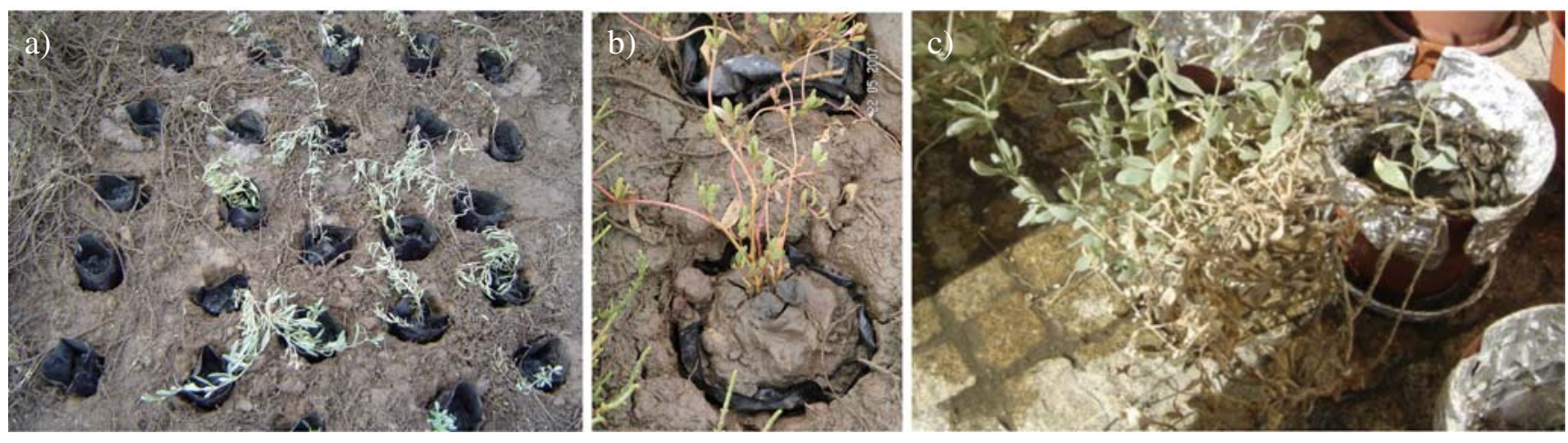

Fig. 1 Pictures from the H. portulacoides study. a Litterbags planting area in Comporta; $\mathbf{b}$ a detail of a litterbag; $\mathbf{c}$ a vase of the laboratorial study 
deionized water, dried at room temperature, homogenized using a planetary ball mill (Fritsch, Pulverisette 6), and stored in a dark place.

The material used for sampling and further analysis was previously cleaned and decontaminated. For this purpose, all the glass and plasticware were washed with soap, rinsed with water, soaked overnight in $20 \%$ nitric acid aqueous solutions, and finally rinsed with deionized water.

\subsection{Total cell counts}

In order to estimate microbial abundance, total cell counts (TCC) of sediment samples were enumerated by the $4^{\prime}, 6^{\prime}-$ diamidino-2-phenylindole (DAPI) direct count method (Kepner and Pratt 1994; Porter and Feyg 1980). For this purpose, $0.1 \mathrm{~g}$ of homogenized sediment were added to $2.5 \mathrm{ml}$ of $9 \mathrm{gL}^{-1} \mathrm{NaCl}$ solution, $200 \mu \mathrm{l}$ of Tween 80 (12,5\% $(v / v))$, and fixed with $1 \mathrm{~mL}$ of $4 \%(v / v)$ formaldehyde. All these solutions were previously filtered through $0.2-\mu \mathrm{m}$ filters. Samples were stirred at $150 \mathrm{rpm}$ for $15 \mathrm{~min}$, followed by sonication for $20-30 \mathrm{~s}$ at low intensity ( 0.5 cycle, $20 \%$ amplitude). Subsamples of fixed sediment slurries or water samples were then stained with DAPI and incubated in the dark for 12 min (Porter and Feyg 1980). Samples were filtered onto black Nucleopore polycarbonate filters $(0.2-\mu \mathrm{m}$ pore size, $25 \mathrm{~mm}$ diameter, Whatman, UK) under gentle vacuum and washed with autoclaved, $0.2-\mu \mathrm{m}$ filtered, distilled water. Membranes were set up in glass slides and cells counted at $\times 1,875$ on an epifluorescence microscope (Laphot, Nikon, Japan).

\subsection{Butyltin analysis}

Butyltins analysis were performed using a method previously validated using certified reference material PACS-2 (from the National Research Council of Canada), which provided LODs of $0.003 \mathrm{ng} / \mathrm{g}$ (as Sn) for MBT, $0.01 \mathrm{ng} / \mathrm{g}$ (as Sn) for DBT, and $0.003 \mathrm{ng} / \mathrm{g}$ (as $\mathrm{Sn}$ ) for TBT and linear ranges between 0.01 and 1,200 ng/g (or more; as Sn) (Carvalho et al. 2007). Butyltins were extracted from about $0.5 \mathrm{~g}$ of sediment with $3 \mathrm{~mL}$ of $6 \mathrm{M}$ hydrochloric acid/ethanol 1:1 $(v / v)$ mixture, using an ultrasonic bath for $2 \mathrm{~h}$, and then centrifuged. A $50-\mu \mathrm{L}$ aliquot of the extract was then put into a vial containing $500 \mu \mathrm{L}$ of buffer solution $(\mathrm{pH}=4.3)$, and the required water to accomplish a total solution volume of $10 \mathrm{~mL}$ per vial, where the fiber was introduced for headspace solid-phase micro-extraction (SPME). Attending to the complex matrix of the sediments, the analytes were always quantified by the standard addition method. For analysis, preconcentration of TBT, DBT, and MBT was performed using an automated sampler (Combi Pal model, CTC Analytics) for HS-SPME and in situ derivatization using $2 \%(w / v) \mathrm{NaBEt}_{4}$. The analytes were desorbed from the fiber to a Varian 3900 gas chromatograph, equipped with a split/ splitless injector port, a SPME liner $(0.8 \mu \mathrm{m})$ and a microseal septum system (Merlin, Half Moon Bay, CA), a CP-Sil 8CB Low Bleed/MS (Varian) column $(60 \mathrm{~m}$ length $\times 0.250 \mathrm{~mm}$ diameter, $0.25 \mu \mathrm{m}$ film thickness) coupled to a Varian Saturn 2000 mass spectrometer (working with tandem mass spectrometry).

\subsection{Sediment characterization}

Organic matter (OM) contents of the sediments were estimated by loss on ignition $\left(4 \mathrm{~h}\right.$ at $\left.500^{\circ} \mathrm{C}\right)$. Grain size analyses were performed by dry sieving.

Sediment collected at Lisnave site and used in the ex situ study contained $99 \%$ of fine-grain fraction $(<0.063 \mathrm{~mm})$ and about $10 \% \mathrm{OM}$. The level of TBT was around $94 \mathrm{ng} \mathrm{Sn}$ per gram, higher than the range established by OSPAR (1997) as provisional ecotoxicological assessment criteria $(0.002-0.02 \mathrm{ng} / \mathrm{g})$ and also higher than the Australian interim sediment quality guideline ISQG-High $(29 \mathrm{ng} / \mathrm{g})$ (ANZECC and ARCMANZ 2000). In addition, the sediment from Lisnave site contained many other pollutants besides tributyltins, including organochlorine pesticides (OCPs) (Carvalho et al. 2009a) and trace metals (Almeida et al. 2008), which may condition and possibly limit the growth of microorganisms at the rhizosphere of the plant. Comporta site was cleaner. Previous studies show that sediment from this area presented lower levels of metals (Almeida et al. 2008), OCPs (Carvalho et al. 2009a), and TBTs (Carvalho et al. 2009b) than Lisnave site.

Sediment from Cávado River estuary used in the laboratorial study presented $11 \%$ of $\mathrm{OM}$ and $67 \%$ of the fine-grain fraction $(<0.063 \mathrm{~mm})$. It contained only $2 \mathrm{ng} \mathrm{Sn}$ per gram TBT.

Sediments of the Marim channel site displayed OM content between $5 \%$ and $7 \%$, depending on the depth, and a percentage of fine-grain fraction between $2 \%$ (at surface) and $13 \%$ (in the deeper layer, $25-30 \mathrm{~cm}$ depth). In terms of trace metals, sediments of the Marim channel site can be classified according to Portuguese legislation (DR 2007) as trace/lightly contaminated by lead, chromium, and nickel.

\subsection{Data analysis}

For each study, butyltin levels and microbial abundance in different samples were compared using a one-way ANOVA at $99 \%$ and $95 \%$ confidence levels, respectively.

\section{Results and discussion}

The levels of TBT and metabolites in sediments observed in the ex situ and laboratorial studies are shown 
in Table 1 . In both cases, $H$. portulacoides was able to enhance TBT remediation in about $30 \%$, in comparison with natural attenuation.

It was also observed that $H$. portulacoides favored growing of bacteria among roots, though the TCC difference between nonvegetated and vegetated sediments was statistically significant only in the laboratorial study (Fig. 2).

The two studies involving $H$. portulacoides differed in several aspects, namely as follows: (a) composition of sediments (see Section 2.4); (b) environmental conditions (experiments in the field were subjected to tides, the sediments being periodically inundated with salt water, whereas in lab experiments, the plants were periodically watered and emended with nutrients); (c) extent of the experiments ( 9 months in the ex situ study vs. 12 months in the laboratorial study); (d) transplant recovering at the end of the experiments (in the ex situ study plants presented some brown coloring and some stems were without leaves, whereas in the lab study, the plants looked like well adapted, displaying several new stems and leaves); (e) final belowground plant biomass was $20 \mathrm{~g} \mathrm{~kg}_{\text {dry sediment }}{ }^{-1}$ in the ex situ study vs. $30 \mathrm{gkg}^{-1}(50 \%$ higher $)$ in the lab experiment. In addition, TCC revealed (Fig. 2) that the number of bacteria present at the end of the experiments was higher in the vegetated sediments than in the nonvegetated ones in both studies, but the difference was much more stressed in the laboratorial one: $46 \%$ (ex situ) vs. $160 \%$ (lab study). Therefore, $H$. portulacoides could favor the growing of bacteria, which very probably had a relevant role on butyltins' degradation. Partial uptake of butyltins by plant root might also occur as has been observed in other studies (Lespes et al. 2009), though that was not experimentally confirmed in the present work. Anyway, $H$. portulacoides could reduce markedly the mobility and availability of TBT in the sediments. Higher values of both belowground plant biomass and TCC observed in the lab study is compatible with the globally higher removal of butyltins observed in this case (Fig. 2). Therefore, this work demonstrated that $H$. portulacoides has potentiality to be used for biological remediation of TBT in polluted sediments.

It is worthy of note that in the ex situ study, the number of microorganisms initially present in the Lisnave sediment decreased very markedly as a consequence of its translocation for the Comporta site (compare in Fig. 2 initial and final TCC in the control sample). This may be a consequence of the differences in biotic and abiotic environmental conditions existing between Lisnave and Comporta sites.

In the laboratory study, a decrease of the number of microorganisms occurred in the nonvegetated sediment during the experiments (Fig. 2), probably as a result of changes in the environmental conditions as well as sediment doping with butyltins. However, in this case, the presence of $H$. portulacoides could enhance the bacterial development in such a way that the final number of bacteria in vegetated sediment was significantly higher than that was present in the initial nonvegetated sediment.

Concerning the in situ study, the levels of TBT, DBT, and MBT determined in nonvegetated sediment and in those colonized by $S$. maritima or $S$. fruticosa are shown in Table 2. Measurable levels of TBT were only observed for nonvegetated sediment (suggesting a higher persistence in the absence of plants) and only at surface, $0.24 \mathrm{ng}$ Sn per gram and at the layer $10-15 \mathrm{~cm}$ depth, $0.78 \mathrm{ng}$ Sn per gram. For the other layers of the non-vegetated sediment and for rooting sediment of both plants, TBT were below the limit

Table 1 Initial and final levels of butyltins (expressed in nanograms of Sn per gram of dry sediment) and percentages of remediation obtained in the studies involving $H$. portulacoides

\begin{tabular}{|c|c|c|c|c|c|c|}
\hline \multirow[t]{2}{*}{ Sample } & \multicolumn{2}{|l|}{$\mathrm{TBT}^{\mathrm{a}}$} & \multicolumn{2}{|l|}{$\mathrm{DBT}^{\mathrm{a}}$} & \multicolumn{2}{|l|}{$\mathrm{MBT}^{\mathrm{a}}$} \\
\hline & ng Sn per gram & $\%$ Remediation & ng Sn per gram & $\%$ Remediation & ng Sn per gram & $\%$ Remediation \\
\hline \multicolumn{7}{|l|}{ 9-month ex situ study } \\
\hline Initial sediment & $94 \pm 15 \mathrm{a}$ & & $155 \pm 23 \mathrm{a}$ & & $464 \pm 28 \mathrm{a}$ & \\
\hline Final sediment & $92 \pm 12 \mathrm{a}$ & 2 & $96 \pm 28 b$ & 38 & $415 \pm 21 \mathrm{a}$ & 11 \\
\hline Final rhizosediment & $66 \pm 11 b$ & 30 & $87 \pm 21 b$ & 44 & $329 \pm 11 b$ & 29 \\
\hline \multicolumn{7}{|c|}{ 12-month laboratory study } \\
\hline Initial sediment & $244 \pm 13 \mathrm{a}$ & & $732 \pm 26 a$ & & $1,677 \pm 281 \mathrm{a}$ & \\
\hline Final sediment & $145 \pm 10 \mathrm{~b}$ & 41 & $374 \pm 13 b$ & 49 & $1,527 \pm 41 \mathrm{a}$ & 9 \\
\hline Final rhizosediment & $61 \pm 10 c$ & 75 & $163 \pm 20 c$ & 78 & $1,684 \pm 201 \mathrm{a}$ & - \\
\hline
\end{tabular}

Initial and final sediment refer to non-vegetated sediment. Rhizosediment refers to sediment among plant roots and rhizomes

The same letter indicates not significantly different levels and different letters mean statistically significant differences within butyltin species

${ }^{a}$ Mean values of at least two independent samples, each one analyzed in triplicate 


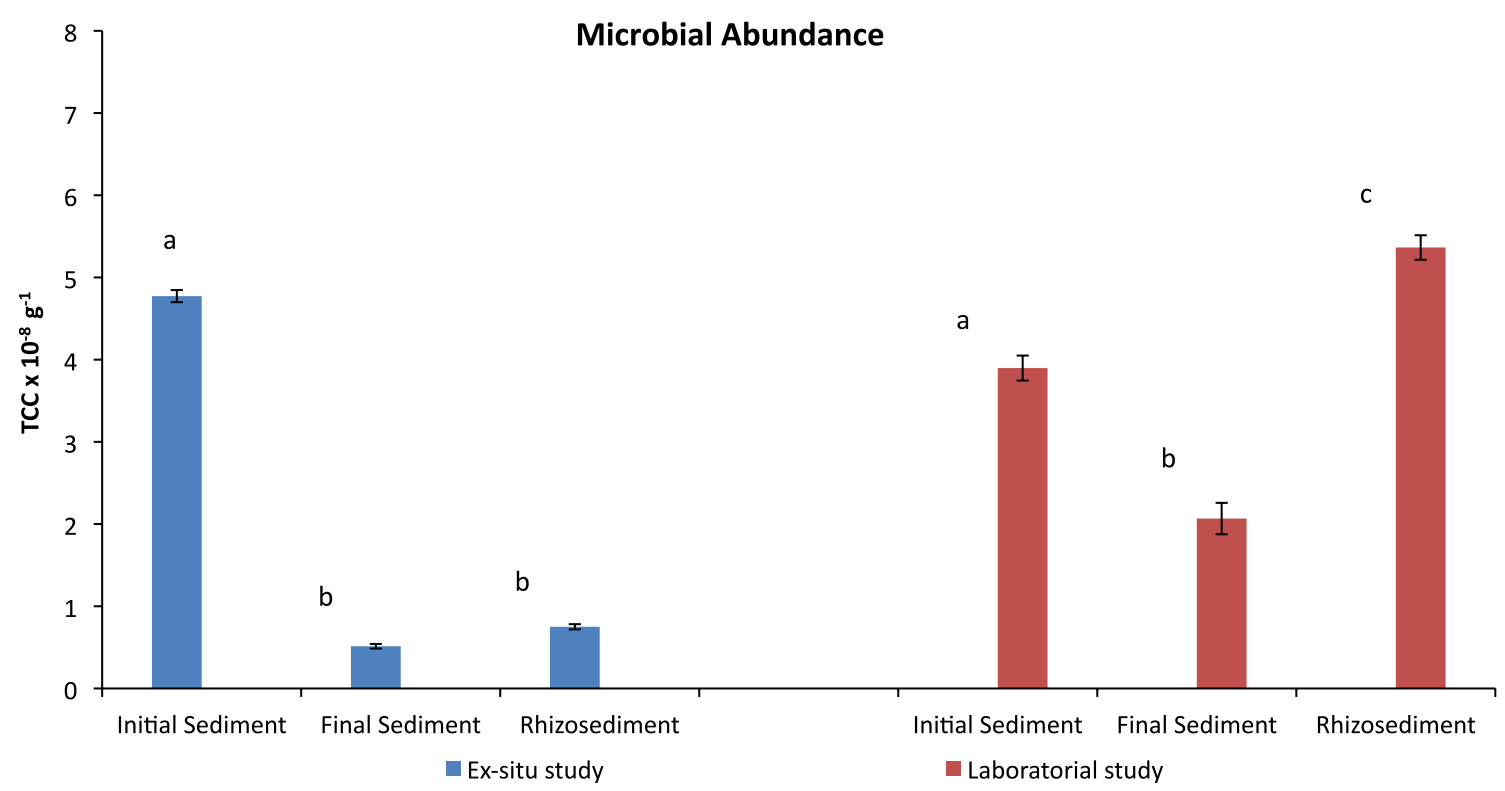

Fig. 2 Microbial abundance in sediments estimated by TCC $\left(\mathrm{g}^{-1}\right)$ obtained in the studies involving $H$. portulacoides. Initial and final sediment refer to nonvegetated sediment. Rhizosediment refers to sediment among plant roots and rhizomes. The same letter indicates not significantly different levels, and different letters mean statistically significant differences within the study
Table 2 Butyltins concentrations (average \pm standard deviation $(n=3))$ observed in the in situ study carried out at Marim channel in Ria Formosa lagoon

\begin{tabular}{llll}
\hline TBT & DBT & MBT & OM \\
ng Sn per gram & ng Sn per gram & ng Sn per gram & $\%$ \\
\hline
\end{tabular}

Nonvegetated sediment

Depth $(\mathrm{cm})$

$\begin{array}{lllll}0-5 & 0.24 \pm 0.05 & <0.01^{\mathrm{a}} & 2 \pm 1 & 4.7 \\ 5-10 & <0.003^{\mathrm{a}} & <0.01^{\mathrm{a}} & 0.7 \pm 0.1 & 4.2 \\ 10-15 & 0.78 \pm 0.02 & 0.5 \pm 0.5 & 1.1 \pm 0.7 & 6.2 \\ 15-20 & <0.003^{\mathrm{a}} & 2.5 \pm 0.3 & 1.6 \pm 0.3 & 7.1 \\ 20-25 & <0.003^{\mathrm{a}} & <0.01^{\mathrm{a}} & <0.003^{\mathrm{a}} & 6.0 \\ 25-30 & <0.003^{\mathrm{a}} & <0.01^{\mathrm{a}} & 0.07 \pm 0.05 & 6.5\end{array}$

Rhizosediment of S. maritima

Depth (cm)

$\begin{array}{llllr}0-5 & <0.003^{\mathrm{a}} & 3.3 \pm 0.7 & 4 \pm 1 & 14.0 \\ 5-10 & <0.003^{\mathrm{a}} & <0.01^{\mathrm{a}} & 2 \pm 2 & 12.4 \\ 10-15 & <0.003^{\mathrm{a}} & <0.01^{\mathrm{a}} & 0.3 \pm 0.3 & 8.9 \\ 15-20 & <0.003^{\mathrm{a}} & <0.01^{\mathrm{a}} & 1.2 \pm 0.8 & 7.9 \\ 20-25 & <0.003^{\mathrm{a}} & <0.01^{\mathrm{a}} & 1 \pm 1 & 8.1 \\ 25-30 & <0.003^{\mathrm{a}} & <0.01^{\mathrm{a}} & <0.003^{\mathrm{a}} & 8.2\end{array}$

Rhizosediment of $S$. fruticosa

Depth $(\mathrm{cm})$

\begin{tabular}{lllll}
$0-5$ & $<0.003^{\mathrm{a}}$ & $<0.01^{\mathrm{a}}$ & $1.9 \pm 0.6$ & 7.7 \\
$5-10$ & $<0.003^{\mathrm{a}}$ & $<0.01^{\mathrm{a}}$ & $1.6 \pm 0.4$ & 4.8 \\
$10-15$ & $<0.003^{\mathrm{a}}$ & $<0.01^{\mathrm{a}}$ & $0.6 \pm 0.2$ & 6.1 \\
$15-20$ & $<0.003^{\mathrm{a}}$ & $<0.01^{\mathrm{a}}$ & $0.9 \pm 1.0$ & 5.5 \\
$20-25$ & $<0.003^{\mathrm{a}}$ & $2 \pm 2$ & 8.8 \\
$25-30$ & $<0.003^{\mathrm{a}}$ & $<0.01^{\mathrm{a}}$ & $5 \pm 2$ & 6.0 \\
\hline
\end{tabular}

Rhizosediment refers to sediment among plant roots and rhizomes

a Limit of detection of the analytical method 
of detection of the analytical method, which was of $0.03 \mathrm{ng}$ Sn per gram (Carvalho et al. 2007), Similarly to TBT, its metabolite DBT was only found (detectable levels $>0.01 \mathrm{ng}$ Sn per gram) for nonvegetated sediment between 10 and $20 \mathrm{~cm}$ depth and for surface rooting sediment of $S$. maritima. In contrast, MBT was found in most samples of either nonvegetated or rooting sediments (Table 2).

Absence of measurable TBT or DBT signals might be a result of insufficient extraction of the chemicals from sediment, as organic matter can trap them. However, the analytical method used in this work has been validated through successful application to suitable reference sediments (Carvalho et al. 2007). Therefore, very probably, the absence of measurable signals of TBT and DBT in rhizosediments (sediments among plant roots and rhizomes) of both $S$. maritime and $S$. fruticosa resulted of their faster removal from the colonized sediments. The presence of significantly higher levels of MBT in some layers of rhizosediments than in nonvegetated sediment is compatible with this hypothesis.

The results of this in situ study suggest that both tested salt marsh plants contributed for TBT and DBT remediation in sediments from Ria Formosa, where the levels of butyltin contamination were much higher in the past (Cortez et al. 1993), when TBT has been included in the paint of boats as antifouling agents. In Ria Formosa, plenty of fishing and shipping activities use to occur all over the year. Recently, the mechanisms of accumulation of TBT were identified in different development stages of the clam $R$. decussatus from Olhão channel (other a tributary of Ria Formosa lagoon) and have been reported that this is one of the most contaminated areas of south coast of Portugal (Bebianno 2007). Therefore, both S. maritima and $S$. fruticosa seem to have potentialities for remediation of TBT and DBT in sediments.

\section{Conclusion}

This work demonstrated that sediments colonized both ex situ and at lab by the halophyte $H$. portulacoides displayed TBT levels about $30 \%$ lower than those for nonvegetated sediments with identical initial composition, after 912 months of plant exposure. In addition, H. portulacoides showed to be able of stimulating bacterial growth in the plant rhizosphere, which probably included degraders of TBT. Therefore, H. portulacoides showed to have potentiality to be used for enhancing TBT remediation in sediments from salted areas.

In an in situ study, which compared the levels of TBT, DBT, and MBT in nonvegetated sediment and in sediments colonized by either $S$. maritima or $S$. fruticosa from the same area, TBT and DBT were only detected in non- vegetated sediment, whereas MBT was quantified in most samples. These results suggested that the two salt marsh plants enhanced TBT and DBT removal from sediment. As a consequence of TBT and DBT degradation, an increase of MBT level may occur temporally. Nevertheless, MBT is also remediated, once its concentration does not increase as much as expected attending to DBT and TBT degradation observed. In addition, as MBT is the less toxic of all TBTs (Antizar-Ladislao 2008), it seems that temporary accumulation of MBT in sediments during TBT phytoremediation will not be of relevant concern.

Therefore, the application of halophytes in technology for TBT remediation in sediments seems to be efficient, either in situ or ex situ, cost effective, and nondestructive, despite the fact that it has been rarely used for this purpose so far.

Acknowledgments The authors acknowledge the Portuguese Foundation for Science and Technology for the financial support of the project "Rhizosphere biogeochemistry and its relevance for toxicity endpoints and phytoremediation" (POCTI/CTA/48386/2002), equipment (REEQ/304/QUI/2005) and Pedro Carvalho's PhD fellowship (SFRH/BD/44934/2008).

\section{References}

Almeida CMR, Mucha AP, Bordalo AA, Vasconcelos MTSD (2008) Influence of a salt marsh plant (Halimione portulacoides) on the concentrations and potential mobility of metals in sediments. Sci Total Environ 403:188-195

Anderson BA, Unger MA, Moore KA (2002) Fate of tributyltin in a created tidal wetland. Environ Toxicol Chem 21:1176-1183

Antizar-Ladislao B (2008) Environmental levels, toxicity and human exposure to tributyltin (TBT)-contaminated marine environment. A review. Environ Int 34:292-308

ANZECC \& ARCMANZ (2000) Australian water quality guidelines for fresh and marine waters, National Water Quality Management Strategy. Australian and New Zealand Environment and Conservation Council, Canberra

Bebianno MJ (2007) Impact of metallic and organic contamination in the marine environment, UALGzine. Sciences of Sea, pp 17-18

Bhosle NB, Garg A, Harji R, Jadhav S, Sawant SS, Krishnamurthy V, Anil C (2006) Butyltins in the sediments of Kochi and Mumbai harbours, west coast of India. Environ Int 32:252-258

Birchenough AC, Barnes N, Evans SM, Hinz H, Kronke I, Moss C (2002) A review and assessment of tributyltin contamination in the North Sea, based on surveys of butyltin tissue burdens and imposex/intersex in four species of neogastropdods. Mar Pollut Bull 44:534-543

Carvalho PN, Pinto LF, Basto MCP, Vasconcelos MTSD (2007) Headspace solid-phase micro-extraction and gas chromatographyion trap tandem mass spectrometry method for butyltin analysis in sediments: Optimization and validation. Microchem J 87:147-153

Carvalho PN, Rodrigues PNR, Basto MCP, Vasconcelos MTSD (2009a) Organochlorine pesticides levels in Portuguese coastal areas. Chemosphere 75:595-600

Carvalho PN, Rodrigues PNR, Basto MCP, Vasconcelos MTSD (2009b) Butyltin levels in several Portuguese coastal areas. Environ Monit Assess 159:183-190 
Cornelis C, Bierkens J, Joris I, Nielsen P, Pensaert S (2006) Quality criteria for re-use of organotin-containing sediments on land. $\mathrm{J}$ Soils Sediments 6:156-162

Cortez L, Quevauviller P, Martin F, Donard OFX (1993) Survey of butyltin contamination in Portuguese coastal environments. Environ Pollut 82:57-62

DR (2007) Portaria n. ${ }^{\circ} 1450 / 2007$, Diário da Republica Portuguesa $1^{\text {a }}$ Série, $\mathrm{N}^{\circ} 217$ de 12-11-2007.

Fent K (1996) Ecotoxicology of organotin compounds. Crit Rev Toxicol 26:1-117

Hoagland DR, Arnon DI (1950) The water-culture method for growing plants without soil (CAES. Circular 347). California Agricultural Experiment Station, Davis, p 32

Hoch M (2001) Organotin compounds in the environment - an overview. Appl Geochem 16:719-743

Kennish MJ (2001) Practical handbook of marine science, 3rd edn. CRC, New York, p 876

Kepner RL Jr, Pratt JR (1994) Use of fluorochromes for direct enumeration of total bacteria in environmental samples: Past and present. Microbiol Rev 58:603-615

Kim NS, Shim WJ, Yim UH, Ha SY, Park PS (2008) Assessment of tributyltin contamination in a shipyard area using a mussel transplantation approach. Mar Pollut Bull 57:883-888

Lespes G, Marcic C, Heroult J, Le Hecho I, Denaix L (2009) Tributyltin and triphenyltin uptake by lettuce. J Environ Manag 90:S60-S68
Liu S-M, Hsia M-P, Huang C-M (2006) Accumulation of butyltin compounds in cobia Rachycentron canadum raised in offshore aquaculture sites. Sci Total Environ 355:167-175

Marcic C, Le Hecho I, Denaix L, Lespes G (2006) TBT and TPhT persistence in a sludged soil. Chemosphere 65:2322-2332

Nishikawa JI, Mamiya S, Kanayama T, Nishikawa T, Shiraishi F, Horiguchi T (2004) Involvement of the Retinoid X Receptor in the Development of Imposex Caused by Organotins in Gastropods. Environ Sci Technol 38:6271-6276

Novak J, Trapp S (2005) Growth of plants on TBT-contaminated harbour sludge and effect on TBT removal. Environ Sci Pollut Res 12:332-341

OSPAR (1997) Oslo and Paris convention for the prevention of marine pollution, Annex 6. Joint Meeting of the Oslo and Paris Comissions, Brussels

Porter KG, Feyg YS (1980) The use of DAPI for identifying and counting aquatic microflora. Limnol Oceanogr 25:943948

Santos MM, Vieira N, Reis-Henriques MA, Santos AM, Gomez-Ariza JL, Giraldez I, ten Hallers-Tjabbes CC (2004) Imposex and butyltin contamination off the Oporto Coast (NW Portugal): a possible effect of the discharge of dredged material. Environ Int 30:793-798

Suehiro F, Kobayashi T, Nonaka L, Tuyen B, Suzuki S (2006) Degradation of tributyltin in microcosm using Mekong River sediment. Microb Ecol 52:19-25 